\title{
離散化構造要素を用いたトポロジー最適化*
}

\author{
竹澤晃 弘*1, 西脇眞二*2, 泉井一 浩*2
}

吉 村 允 孝*3, 西 垣 英一*4, 鶴 見 康 昭*4

\section{Topology Optimization Using Structural Discrete Elements}

\author{
Akihiro TAKEZAWA, Shinji NISHIWAKI*5, Kazuhiro IZUI, \\ Masataka YOSHIMURA, Hidekazu NISHIGAKI and Yasuaki TSURUMI \\ ${ }^{* 5}$ Department of Precision Engineering, Kyoto University, \\ Yoshida-honmachi, Sakyo-ku, Kyoto, 606-8501 Japan
}

\begin{abstract}
Computer Aided Engineering (CAE) has been successfully utilized in mechanical industries, but few CAE tools that include structural optimization can be utilized at the conceptual design phase, since the development of such tools has been based on continuum mechanics that limit the provision of useful design suggestions at this phase. In order to mitigate this problem, a new type of CAE based on classical structural mechanics, First Order Analysis (FOA), is proposed. In this paper, we present a topology optimization method that corresponds to FOA concepts. This optimization method is constructed, based on discrete and function-oriented elements such as frame, panel and spring elements, and sequential convex programming. In addition, examples are provided to show the utility of the methodology presented here for mechanical design engineers.
\end{abstract}

Key Words : Design Engineering, Optimum Design, Structural Analysis, Framed Structure, Sensitivity Analysis, Computer Aided Engineering

\section{1. 粕言}

近年の機械製品の開発において, $\mathrm{CAE}^{(1)}$ は必要不可欠 なものになっている.コンピュータ技術の飛羁的な発展 に伴い, CAEは, 試作品を作成すること無しに機械製品 の性能を定量的に評価可能とし，必要な場合には最適設 計技術こ基づき性能改善を行うことも可能となっている. しかし,このようなCAEは, 試作・実験的評価の数值的 代替手法にとどまり, 製品の構想設計段階において, 製 品の基本的な性能に起因する形態・形状を明確化したり， 抜本的な性能向上を狙った構造形態を創出するために利 用することは難しい．

他方, 構想設計段階において, 製品の機能と形態を論 理立てて分析することにより,基本構想を評価する方法 として, QFD法(2)などの種々の方法が提案されている. しかしこれらの方法は,性能の極めて定性的な評価にと

* 原稿受付 2003 年 8 月 5 日.

*1 京都大学大学院工学研究科( 606 -8501 京都市左京区吉田 本町).

*2 正員, 京都大学大学院工学研究科.

*3 正員, フェロー, 京都大学大学院工学研究科.

*4 正員, (株) 豊田中央研究所 (- 480-1192 愛知県愛知郡長久 手町).

E-mail : shinji@ prec.kyoto-u.ac.jp
どまり,力学的観点に基づき機械構造の性能評価をする ことは難しい．

このような問題を解決する方法として, First Order Analysis(3)(以下FOAと略す)が提案されている. FOAは, 設計者に設計要因と性能を力学的に筋道を立てて理解可 能な物理量を提供し,構想設計段階における意思決定を 支援することを目的としている. そして，このような FOAを実現するためには,フレーム要素やパネル要素の ように要素の機能が力学的に明確で,最適構造に内在す る構造的意味や設計指針が得やすい 離散化構造要素に基 ついたトポロジー最適設計法の開発が必要となる.

ところで,従来までの離散化要素を用いた最適化手法 としては, 主にトラス要素を用いた多くの方法(4),(5)が提 案されている. しかし, トラス要素は極めて単純化され た要素であり,これらの方法を実際の機械設計に適用す ることは難しい.これに対して, 西脇ら(6)や藤井ら(7)は， 実用的な要素である骨組み要素に基ついた方法を提案し ているが,より一般的な構造設計においては, 性能を骨 組み要素だけで評価することには限界がある.

そこで, 本研究では, 自動車のボデー・サスペンショ ンのようなフレーム構造とパネル構造て構成される機械 構造への適用を目指し,より一般的な離散化要素に基づ 
いた最適設計法を構筑する.すなわち,フレーム要素,パ ネル要素と,機械設計に必要不可欠な結合部を評価する ためのばね要素に基づいたトポロジー最適化法を開発す ることにより,上述の機械製品の構想設計一の適用を検 討する.

以下， 2 章では，構想設計段階で最も一般的な最適化 問題である剛性最大化問題について, 目標関数の定式化 を行う. 次に, 離散化要素における設計変数の設定とそ の要素の定式化を行い, マルチローディング(8)の考え方 を基に, 最適化問題を定式化する. そして,この定式化 に基づき,逐次凸関数近似法を用いたトポロジー最適化 アルゴリズムを構筑する. 最後に, 3章では簡単な数值 例により，本報で提唱する方法論の妥当性を検証する.

\section{2. 定式化}

2. 1 粕生の定式化 図 1 に示すように, 節点 間を離散化弾生要素で連結した構造物の静的な変形問題 について考える. 構造物の各節点は並進方向に $x, y, z$ の 3 自由度, 回転方向に $\theta_{x}, \theta_{y}, \theta_{z}$ の 3 自由度を持つものと する. そして, 図1に示した弾性構造物の境界 $\Gamma_{\mathrm{d}}$ を完 全固定し, 構造物内の節点 $Q_{i}$ に荷重ベクトルfを作用さ せたときの構造物の変形ベクトルをuであるとする.こ こで $f, \boldsymbol{u}$ は次式で表される.

$$
\begin{aligned}
& \boldsymbol{f}=\left\{0,0,0, \cdots, f_{x_{i}}, f_{y_{i}}, f_{z_{i}}, f_{\theta x_{i}}, f_{\theta y_{i}}, f_{\theta z_{i}}, \cdots,\right. \\
& 0,0,0\}^{\mathrm{T}}
\end{aligned}
$$

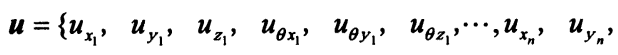

$$
\begin{aligned}
& \left.u_{z_{n}}, \quad u_{\theta x_{n}}, \quad u_{\theta y_{n}}, \quad u_{\theta z_{n}}\right\}^{T} .
\end{aligned}
$$

なおこここでは简略化のため構造物の 1 節点に荷重をか けた場合を考えているが,複数の荷重を複数の節点に同 時に作用させてもよいものとする.

この時, 次式に示す荷重ベクトルと変形ベクトルuの 積である平均コンプライアンス $\left(99\right.$ が, 節点 $Q_{i}$ に荷重べ クトルを作用させた場合の剛性の尺度となる.

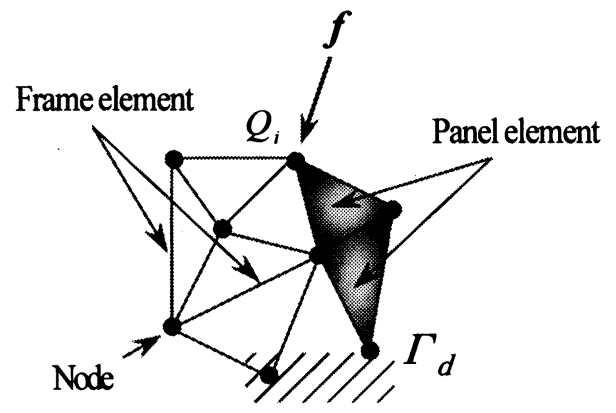

Fig.1 An elastic structure subjected to a force.

$$
l=\boldsymbol{f} \cdot \boldsymbol{u}=\boldsymbol{f}^{T} \boldsymbol{u}
$$

すなわち,このlを最小化することにより，剛性を最大 化することができる.

2. 2 トポロジ一最化の考え方 トポロジー 最適化の基本的な考え方は固定設計領域(9) の設定と次式 に示寸特性関数 $\chi_{\Omega}$ の導入にある.すなわち, 最適構造と なるべき本来の設計領域 $\Omega_{d}$ を包括する固定設言十領域 $D$ を最初に設け，その固定設計領域と特性関数 $\chi_{\Omega}$ を用い て, 最適化問題を材料分布問題, あるいは要素配置問題 に置き換えることにある.

$$
\chi_{\Omega}(x)= \begin{cases}1 & \text { if } \quad x \in \Omega_{d} \\ 0 & \text { if } \quad x \in D \backslash \Omega_{d}\end{cases}
$$

上式の $\chi_{\Omega}$ を用いれば固定設計領域 $D$ 内の座標 $x$ にある 点が $\Omega_{d}$ 内にあるかの判断をすることにより，最適構造を 決定することができる.この特性関数を離散化要素に適 用する場合, 要素が存在するかどうかの有限個の不連続 性が存在するという問題が生じる. そこで, ここでは密 度法(10)的な考え方に基ついた次式により，特性関数を連 緛関数に置き換える設計空間の緩和を行う.

$$
\rho_{v}^{P} \approx \chi_{\Omega}(x)
$$

ここで, $\rho_{v}$ は正規化された設計変数で,

$$
0 \leq \rho_{v} \leq 1
$$

なる值をとる. またPは $\rho_{v}$ にペナルティを与えるパラ メータで, これにより, 計算上の体積密度の相違は, 実 際の相違よりも強調することができる. 式(5)を用いれ ば, 最適設計問題を固定設計領域 $D$ 内における構造要素 の連続的な分布問題に置き換えることができる.

2. 3 設計要素の定式化 前述のように, 本研 究では設計要素としてフレーム要素, パネル要素, ばね 要素を想定している.以下その詳細について説明する.

2. 3. 1 フレーム要素の定式化 フレーム要 素は軸力,曲げ,ねじりに対する 6 自由度の剛性を持つ. 本研究では, 最も単純な場合を想定し, 断面は中実円と 仮定して,次式の正規化された断面積 $\rho_{A}$ を設計変数とす る.

$$
A=\rho_{A}^{P_{A}} A_{\max }\left(0 \leq \rho_{A} \leq 1\right) \cdots \cdots \cdots \cdots \cdot(7)
$$

ここで $P_{A}$ はペナライゼーションパラメータ, $A$ は断面積, $A_{\text {max }}$ は最大時の断面積である. また, フレーム要素の剛 性マトリクスを作成する際に必要な各物理量は以下のよ うに求められる. フレームの直径をdとすれば,

$$
\rho_{A}^{P_{A}} A_{\max }=\frac{\pi}{4} d^{2} \ldots \ldots \ldots \ldots \ldots \ldots \text { (8) }
$$

なる関係が成り立つので, 断面二次モーメント $I_{y}$ と $I_{z}$ は, 


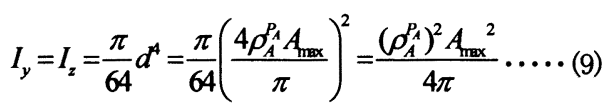

断面二次極モーメントJ $J_{x}$,

$$
J_{x}=\frac{\pi}{32} d^{4}=\frac{\pi}{32}\left(\frac{4 \rho_{A}^{p_{A}} A_{\max }}{\pi}\right)^{2}=\frac{\left(\rho_{A}^{P_{A}}\right)^{2} A_{\max }{ }^{2}}{2 \pi} \cdots \cdots \cdots(10)
$$

となる.上式の関係を用いて要素剛性マトリクスを作成 する.

2. 3.2 パネル要秦の定式化 機械構造を構 成する薄板パネルでは, 面内方向の釣合いが支配的で,パ ネルに求められる剛性は主に面内方向である.これに対 して, 面外方向の剛性は低く, 機械構造の性能としてこ の剛性が要求される場合は少ないので, 面外方向の剛性 は構想設計時の評価においては,無視できると考えられ る.そこで,本研究ではパネル要素の定式化においては, 面内方向の釣り合いのみを考慮する.

パネル要素における設計変数は, 次式の正規化された パネルの厚さ $\rho_{t}$ とする.

$$
t=\rho_{t}^{P_{t}} t_{\max }\left(0 \leq \rho_{t} \leq 1\right)
$$

ここで, $P_{1}$ はペナライゼーションパラメータ, $t_{\text {max }}$ は最大 時の板厚である.

次に応力仮定 ${ }^{(1)}$ に基ついて要素剛性マトリクスの定式 化を行う. 応力仮定では, 面内曲げが支配的な場合につ いて, 比較的精度の良い結果が得られるうえ，応力 $\boldsymbol{s}$ の 補間関数と変位 $\boldsymbol{U}$ の補間関数を独立に定義できるので, パネルの支配的な応力をあらかじめ仮定できる特徽を持 つ. 最初に, 局所座標系と全体座標系の対応を定式化す れば, 次式となる。

$$
x_{i}=\left\{\begin{array}{l}
x_{i} \\
y_{i} \\
z_{i}
\end{array}\right\}=\left\{\begin{array}{l}
\left(X_{i}-X_{c}\right) \cdot e_{x} \\
\left(X_{i}-X_{c}\right) \cdot e_{y} \\
\left(X_{i}-X_{c}\right) \cdot e_{z}
\end{array}\right\} \cdots \cdots \cdots(12)
$$

ここで, $X_{c}$ は要素中心べクトルであり $, \boldsymbol{e}_{x}, \boldsymbol{e}_{y}, \boldsymbol{e}_{z}$ は局所 座標系の単位ベクトルである.上式の局所座標に基づき,

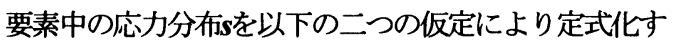
る. まず最初の場合は, 真応力とせん断応力を次式で補 間する場合である.

$$
\begin{gathered}
s=\left\{\begin{array}{c}
\sigma_{x} \\
\sigma_{y} \\
\tau_{x y}
\end{array}\right\}=\left\{\begin{array}{c}
c_{11}+c_{12} y \\
c_{21}+c_{22} x \\
c_{31}
\end{array}\right\} \\
=\left[\begin{array}{lllll}
1 & y & 0 & 0 & 0 \\
0 & 0 & 1 & x & 0 \\
0 & 0 & 0 & 0 & 1
\end{array}\right]\left\{\begin{array}{l}
c_{11} \\
c_{12} \\
c_{21} \\
c_{22} \\
c_{23}
\end{array}\right\}=N_{s} c \cdots \cdots \cdot(13)
\end{gathered}
$$

この場合は一般のパネルと同様に真応力とせん断応力を 支持することができる. また，二番目の場合はせん断応 力のみを次式で補間する場合である.

$$
\boldsymbol{s}=\left\{\begin{array}{l}
\sigma_{x} \\
\sigma_{y} \\
\tau_{x y}
\end{array}\right\}=\left\{\begin{array}{c}
0 \\
0 \\
c_{31}
\end{array}\right\}=\left[\begin{array}{lllll}
0 & 0 & 0 & 0 & 0 \\
0 & 0 & 0 & 0 & 0 \\
0 & 0 & 0 & 0 & 1
\end{array}\right]\left\{\begin{array}{c}
c_{11} \\
c_{12} \\
c_{21} \\
c_{22} \\
c_{23}
\end{array}\right\}=N_{s} c
$$

なお,ここで二つのパネル要素を定式化した理由は,こ れら二つの要素を用いて得られた最適解を比較すること により,構造の力学的メカニズムが明確になるからであ る. すなわち, 両者から得た最適構造を力学的見地から 比較すれば，その構造の支配的な応力を判断することが でき, その構造の成り立ち, あるいはしくみを理解でき るからである. 以後, 通常パネルと記述したら式(13)で 定式化したパネルを示し，せん断パネルと記したら式 (14)で定式化したパネルを示す.

また, 変位 $\boldsymbol{U}$ は一般的な双一次の補間関数 $N$ を用いて 次式で表す.

$$
u_{e}=\left\{\begin{array}{l}
u_{x} \\
u_{y}
\end{array}\right\}=N d
$$

dは，4つの節点の変位ベクトルで，これを用いれば微 小ひずみeは変位ベクトルuを用いて次のように表され る.

$$
\boldsymbol{e}=\partial \boldsymbol{u}=\left[\begin{array}{cc}
\frac{\partial}{\partial x} & 0 \\
0 & \frac{\partial}{\partial y} \\
\frac{\partial}{\partial y} & \frac{\partial}{\partial x}
\end{array}\right] \boldsymbol{u}=\partial \boldsymbol{N d}=\boldsymbol{B d} \cdots \cdots(16)
$$

他方, 応力ーひずみ関係式は次のように得られる.

$$
D^{-1} s-e=D^{-1} s-\partial u=0
$$

しかし,この要素では応力と変位を独立に仮定している ため, 式(16)から得られるひずみと，式(17)から得られ るひずみは一致しない.ここでは,

$$
\min _{\boldsymbol{s}} \frac{1}{2} \int_{h_{e}}\left(D^{-1} s-\partial u\right) D\left(D^{-1} s-\partial u\right) d \Omega_{e}, \cdot \cdots(18)
$$

となるように, すなわち, 式(17)をエネルギー残差が最 小になるように緩和することによって,エネルギーの釣 り合いを確保する. ここで, Dは弾性マトリクス, $\Omega_{\mathrm{e}}$ は 要素の領域である. よって式(16), 式(18)より, 次式が 得られる. 
$\int_{\Omega_{e}} \delta s^{T}\left(D^{-1} s-\partial u\right) d \Omega=\delta c \int_{\Omega_{e}} N_{s}^{T} D^{T}\left(N_{s} c-B d\right) d \Omega$

$=\delta c\left(M_{s} c-M_{B} d\right)=0$

式(19)を式(17)に代入して,

$\boldsymbol{e}=D^{-1} s=D^{-1} N_{s} c=D^{-1} N_{s} M_{s}^{-1} M_{B} d=\bar{B} d \cdot(20)$

が得られるので, 要素剛性マトリクスは次式となる.

$K_{e}=\int_{\Omega_{e}} e^{T} \operatorname{Ded} \Omega=\int_{\Omega_{e}} \bar{B}^{T} D \bar{B} d \Omega=M_{B}{ }^{T} M_{s}^{-1} M_{B}$

なお詳細は文献(11)を参照されたい。

2. 3. 3 ばね要素の定式化 ばね要素におけ る設計変数は、正規化されたばね定数 $\rho_{k}$ とする. 但し, 最適な溶接の強さを求めるのではなく,得られた結果を もとに最適な溶接位置を探索する事を目的とする.この 時, 並進に対するばね定数 $k_{t}$ と回転に対するばね定数 $k_{r}$ を次式で示す.

$$
k_{t}=\rho_{k}^{P_{k}} k_{t \max }, \quad k_{r}=\rho_{k}^{P_{k}} k_{r \max } \quad\left(0 \leq \rho_{k} \leq 1\right) \cdots(22)
$$

$P_{k}$ はペナライゼーションパラメータ, $k_{t \text { max }}, k_{r \text { max }}$ はそれ ぞれ，並進，回転に対する最大時のばね定数である. な お, $k_{t_{\max }}, \boldsymbol{k}_{r \text { max }}$ の設定の仕方により, 種々の溶接法を表 現することができる.

2. 4 化問题の定式化 $n_{A}$ 本のフレーム要 素と, $n$ 枚のパネル要素と, $n_{k}$ 個のばね要素で構成される 設計領域 $D$ に, 荷重を別々に作用させるようなマルチ ローディングの問題が $m$ 通りある場合について, 剛性最 大化を行う.すなわち, 荷重ベクトル $\boldsymbol{f}^{j}(j=1, \cdots, m)$ で 表される荷重が作用する時に, 後述する制約条件のもと て剛性の最大化をはかる.なお,境界 $\Gamma_{\mathrm{d}}$ を完全固定して, 荷重を作用させた時の変位を $\boldsymbol{u}^{j}(j=1, \cdots, m)$ とし, 平均 コンプライアンスを $l^{j}(j=1, \cdots, m)$ とする. また, 最適化 の制約条件としては, フレーム, パネル要素については 総体積とし,ばね要素に関しては設計変数 $\boldsymbol{~}_{k_{k} k}$ に比例する コストの総和とする. このとき, 最適化問題は以下のよ うに定式化される.

$$
\underset{\rho_{A, 1,}, \rho_{l, l}, \rho_{k, l, k}}{\operatorname{minimize}} l=\left\{l^{1}, \cdots, l^{j}, \cdots, l^{m}\right\}^{T}
$$

制約条件

$$
V_{B}=\sum_{i_{A}=1}^{n_{A}} \rho_{A, i_{A}} A_{\max } L_{i_{A}} \leq V_{B}^{U}, \quad V_{P}=\sum_{i_{i}=1}^{n_{i}} \rho_{t, i_{t}} t_{\max } A_{t, i_{t}} \leq V_{P}^{U}
$$

又は

$$
\begin{aligned}
& V=V_{B}+V_{P}=\sum_{i_{A}=1}^{n_{A}} \rho_{A, i_{A}} A_{\max } L_{i_{A}}+\sum_{i_{i}=1}^{n_{t}} \rho_{t, i_{i}} t_{\max } A_{t} \leq V^{U} \\
& T C=\sum_{i_{k}=l}^{p} \rho_{k, i_{k}} C_{\max } \leq T C^{U} \\
& 0 \leq \rho_{A, i_{A}} \leq 1 \text { for } i_{A}=1, \ldots, n_{A} \cdots \cdots \cdots \\
& 0 \leq \rho_{t, i_{t}} \leq 1 \text { for } i_{t}=1, \ldots, n_{t} \\
& 0 \leq \rho_{k, i_{k}} \leq 1 \text { for } i_{k}=1, \ldots, n \\
& K u^{j}=f^{j} \text { for } j=1, \ldots, m
\end{aligned}
$$

ここで $\rho_{i, \lambda}$ は $i_{A}$ 番目のフレーム要素の設計変数, $\rho_{t, i}$ は $i$ 番 目のパネル要素の設計変数, $\rho_{k_{k}}$ は $i$ 番目のばね要素の設 計変数, $L_{i_{A}}$ は $i_{A}$ 番目フレーム要素の長さ, $V_{B}$ はフレーム 要素の体積の総和, $V_{B}^{U}$ はフレーム要素の体積制約の上限 值, $A_{t, i_{i}}$ は墦目のパネル要素の面積, $V_{P}$ はパネル要素の 体積の総和, $V_{P}^{U}$ はパネル要素の体積制約の上限值, $V^{U}$ は フレーム要素,パネル要素の体積の総和を制限する体積 制的の上限值, $C_{\text {max }}$ はばね要素一あたりのコストの最

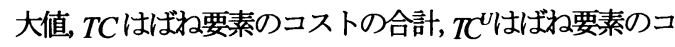
スト制約の上限值, $\boldsymbol{K}$ は設計領域全体の剛性マトリクス である.

上式の多目的問題を解く方法として,本研究ではSunki と Kkuchi ${ }^{(8)}$ の方法に基づく, 次式の目的関数fを用いる.

$$
f=\max _{j=1, \ldots, m} l
$$

上式を用いれば, 平均コンプライアンスが最大のもの を最小化することになるので,剛性がいちばん低い場合 について,剛性が向上されることになる.したがって,結 果的にすべての場合について平均的な剛性を持つ最適構 造が得られることになる.

図2に最適化のフローチャートを示寸.最初に剛性マ トリクス $\boldsymbol{K}$ を求め, 次に, 釣り合い方程式を解いて, 変 位ベクトル $\boldsymbol{u}^{j}$ を求める.その值を用いて平均コンプライ アンスを求める. この時, 体積制約及びばね要素のコス 卜制約を計算し, 収束判定を行う. 目的関数が収束して いれば, 最適化を終了し, 収束していなければ, 平均コ ンプライアンス $l$ と制約条件の, 設計変数 $\rho_{A_{k}}, \rho_{i t}, \rho_{k_{k}}$ に 関する感度を計算し,それを用いて設計変数 $\rho_{i_{k}}, \rho_{i t}, \rho_{k, k}$ を更新する. その後, 剛性マトリクスKを再作成し, 同 様の計算を絽り返す。

設計変数の更新の際の最適化手法には, 逐次凸関数近 似法である CONLIN(Convex Linearization) $)^{(12)}$ を使用する. CONLNは, 剛性問題に対して, 発見的手法無しで高い収 束性が得られる特徵を持っ. CONLINの基本的な考え方 は, 目標関数あるいは制約条件である関数 $h$ を, 


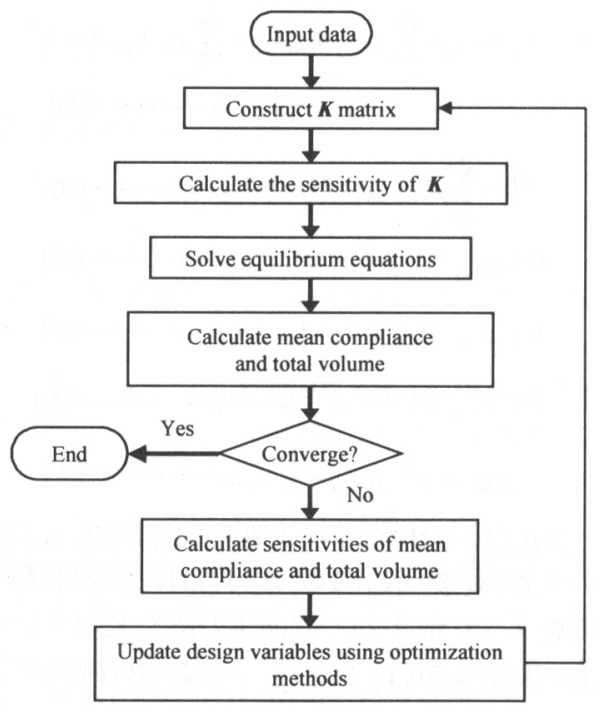

Fig.2 Flowchart of optimization procedure

$$
\eta_{i}=\left\{\begin{array}{c}
d_{i} \text { if } \partial h / \partial d_{i}>0 \\
1 / d_{i} \text { if } \partial h / \partial d_{i}<0
\end{array} \text { for } i=1, \ldots, n\right.
$$

なる媒介変数を用いて近以する事にある.ここで用い る目標関数についは、ひずみエネルギーと同じ次元 を持ち, その感度は負となるので, 上式の二番目の近 似が適用される. 他方, ひずみエネルギーは, 荷重規 定の問題では各要素の岡性の值, すなわち本定式化で は変数 $\rho_{A_{A}}, \rho_{t, i}, \rho_{k_{j_{k}}}$ に対して反比例することになる.こ れは,上式が本来の目標関数に近い形態で近似してい ることを示し, 高い収束性が期待できる.

\section{3. 数值例}

いくつかの数值例により,本研究で提唱する方法論 の妥当性を検証する. なお, 構造物の材料にはいずれ の場合にも鋼を想定し, ヤング率を209GPa，ポアソン 比を 0.3 とした. また, 各設計要素のペナルティを与 えるパラメータ $P_{A}, P_{t}, P_{k}$ は, 設計変数と体積あるい はコストとの関係に物理的な整合性をとるためにそれ ぞれ1とした。

\section{1 パネル要素の定式化の相遠と最適解の}

関係最初に, 2次元のモデルを用いて, 式(13) と 式(14)により定式化される異なるパネル要素と, 最適 解の関係を検討する. 図 3 に設計領域を示す. 設計領 域を $x$ 方向, $y$ 方向にそれぞれ 4 分割し, 分割された各 領域にはパネル要素を配置する. また, 配置された各 パネル要素の周上にはフレーム要素を配置する.さら
Fixed design domain $D$

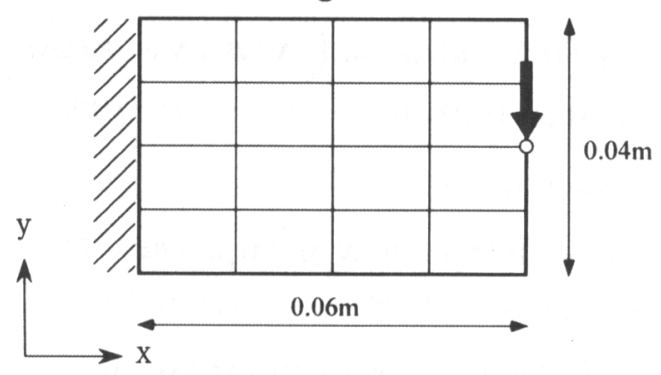

Fig.3 Design domain for 2D model

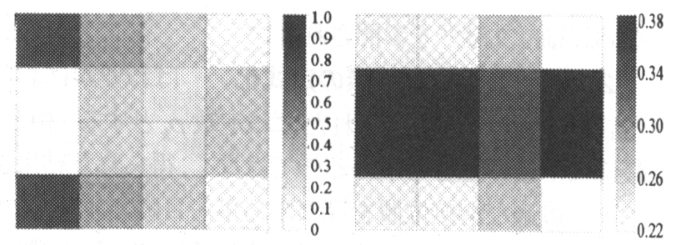

$\begin{array}{ll}\text { (a) Normal panel used } & \text { (b) Shear panel used }\end{array}$

Fig.4 Optimal panel configurations of 2D model

に, 固定設計領域 $D$ の左側を完全固定し, 右側の境界中心 の節点に

$y$ 方向に荷重10.0Nを作用させた場合の最適解を得る.

なお,ここではパネル要素のみを設計要素とし, フレー ム要素は非設計要素とし, フレーム要素の影響を十分小さ いものとし, すべてのフレーム要素の断面積を $1.26 \times 10$ ${ }^{5} \mathrm{~mm}^{2}$ とした. また, 最大時のパネルの厚さ $t_{\max }$ は3. $0 \mathrm{~mm}$, 体 積制約 $V_{P}^{U}$ は全設計領域の $30 \%$ と設定した。

図4に最適構造を示寸.図中(a)の場合は式(13)の通常パ ネルを用いた場合で, (b)の場合は式(14)のせん断パネルを用 いた場合で, 正規化された板厚 $\rho$, の分布を示している.な お, 図中のカラーバーは各最適構造の板厚の差異を明確に するため, $\rho$, の最大値と最小值の間で割り当てた.

図中(a)では,設計領域の左側の上部及び下部の板厚が高 いことがわかる.これは本荷重設定において生じる, $x$ 方向 における真応力が高いために生じた結果と考えられる.こ れに対して図中(b)では, 設計領域の中段部分のパネルの板 厚が高い.これは, せん断パネルはせん断応力しか支持で きず, 結果として, せん断応力が支配的な中央部分に板が 配置されたと考えられる.

3. 2 制約条件の相逞と最適解の関係 次に, ᄀ レーム要素とパネル要素を同時に設計要素とし, 2 つ式 (24) と式(25)に示す二つの体積制約の設定法と最適解の関 係を検討する. なお, 最適化のモデルとしては図 3 の二次 元のモデルを使用し,パネル要素は通常パネルを用いた.ま た, 最大時のフレームの断面積は $1.13 \times 10^{2} \mathrm{~mm}^{2}$, パネルの 最大厚さは3.0mm, 体積制約はいずれの場合においても全 設計領域の $30 \%$ として, 最適化した. 


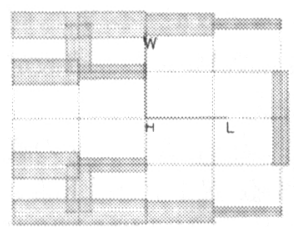

Frame elements

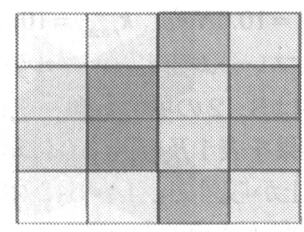

Panel elements (a) Volume constrained by eq.(25)
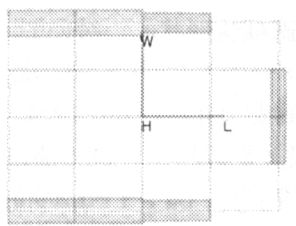

Frame elements

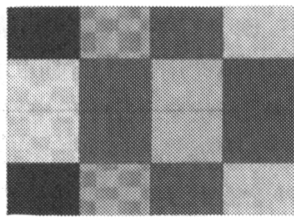

Panel elements

(b) Volume constrained by eq.(26)

Fig.5 Optimal configurations of 2D model constrained by different volume constraints

図 5 に最適構造を示す. 図中(a) は, 式(24)のパネル要 素とフレーム要素に別々の体積制約を設定した場合の結 果で,図中(b)は式(25)の両要素に共通の体積制約を設定 した場合の結果である.両結果を比較寸ると共通の体積 制約を設けた場合の方が,パネルの総体積が多くなって いるのがわかる.これはこの荷重条件では, より多くの 余剩体積をパネルに負担させた方が,より高、剛性が得 られるといらことを示している.

3. 3 設計要素の機能と最適解の関係 次に, 3次元のモデルを用いて設計要素の機能の相違と最適解の 関係を検討寸る.図6に示したように 2 次元の $5 つ の$ 設 計領域を用意し,それにより直方体の各面が設計領域と

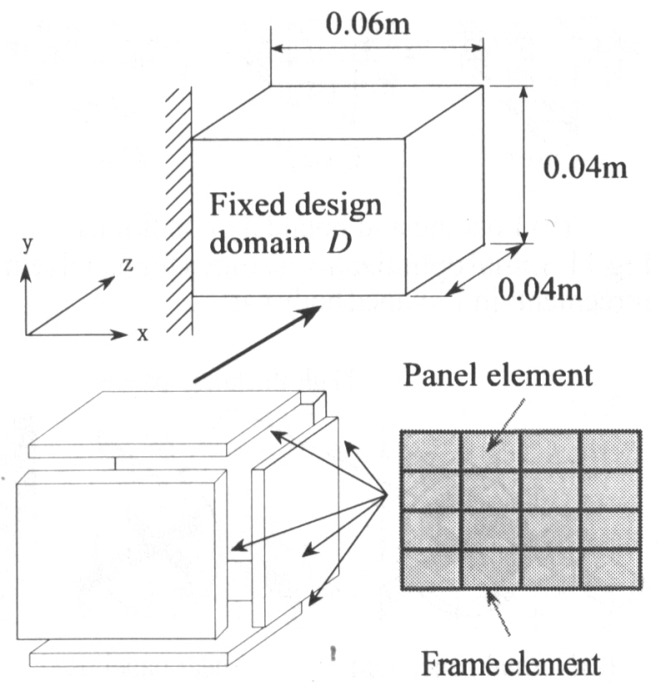

Fig.6 Design domain for 3D model

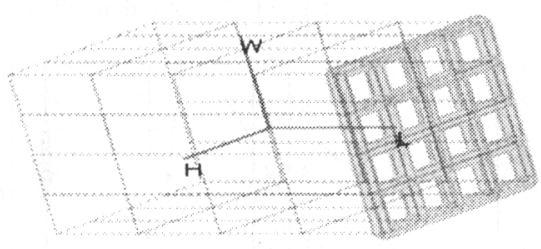

Frame elements

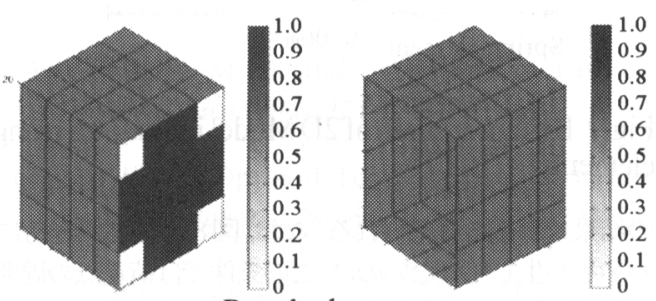

Panel elements

Fig.7 Optimal configurations of 3D model (panel elements defined by eq.(13) used)

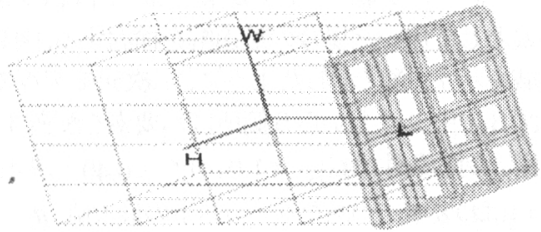

Frame elements

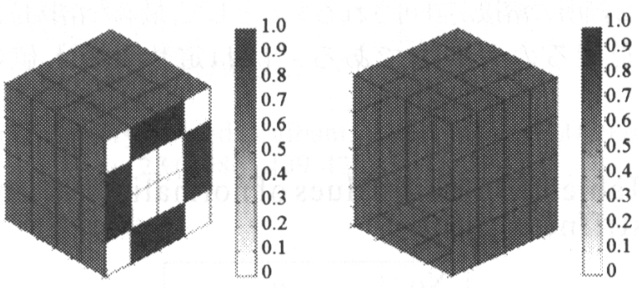

Panel elements

Fig.8 Optimal configurations of $3 \mathrm{D}$ model (panel elements defined by eq.(14) used)

なるように設定する.なお各面の設計領域の設定は図 3 の場合と同一にしている. 固定設計領域 $D$ の左側を完全 固定し, 右側の境界面の中心に $x$ 軸周りにトルク $10.0 \mathrm{~N}$ ・ $\mathrm{m}$ を作用させた場合の最適解を得る. なお, フレームの 最大時の断面積は $2.83 \times 10 \mathrm{~mm}^{2}$, パネルの最大時の厚さ は3.0mmとし,体積制約は式(25)のもと全設計領域の50\% とした.

図7，8に最適構造を示す. 図 7 は通常パネルを用い た場合の結果で,図8はせん断パネルを用いた場合の結 果である.どちらのパネルについても荷重点近傍にのみ フレームが生じ,側面はパネルで占められていることが わかる. 側面において, パネルの種類の違いによらず同 じ形状が得られているのは,せん断が支配的であるため 


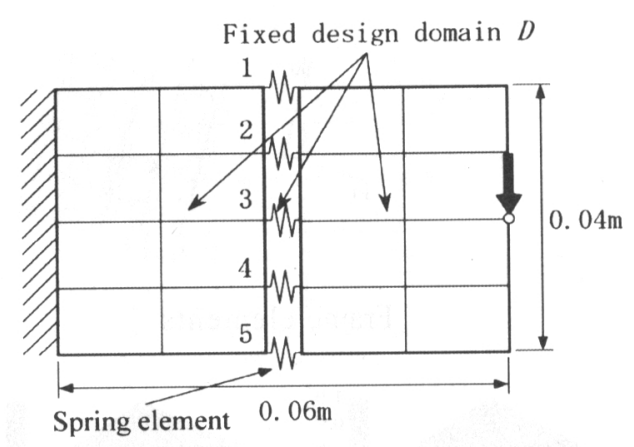

Fig.9 Design domain of 2D Model including spring elements

の結果であると考えられる. なお, 図8で荷重点近傍に パネルが生じていないのは, この条件では荷重点の周囲 は剛体回転を生じ,せん断が生じないためであると考え られる.

\section{4 ばね要素を用いた場合の最適解の導出}

次に, フレーム要素, パネル要素に加え, ばね要素も設 計要素として用いた場合の最適解を検討する.図 9 に設 計領域を示す, 図に示したように, 二次元モデルで使用 した図 3 の中央に上から 5 箇所ばね要素を配置する.ば ね要素の制約条件は $C_{\text {max }}=1.0, T C^{U}=0.40$ と設定した.

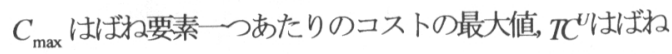
要素のコスト制約の上限值である.つまり5䇢所のうち 2 箇所の溶接が許可されるものとして, 最適な溶接位置 を探るのが目的である。ばね定数の最大值は

Table.1 Optimal values of normalized spring stiffness $\rho_{k}$

\begin{tabular}{|c|c|}
\hline No. & $\rho_{k}$ \\
\hline 1 & 0.999 \\
2 & $0.543 \times 10^{-3}$ \\
3 & $0.111 \times 10^{-4}$ \\
4 & $0.543 \times 10^{-3}$ \\
5 & 0.999 \\
\hline
\end{tabular}

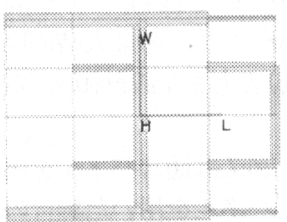

Frame elements

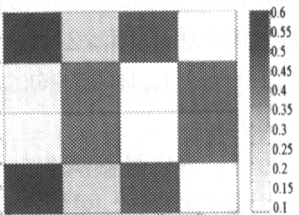

Panel element (Normal panel used)
Fig. 10 Optimal configurations of 2D Model includingspring elements $k_{t \text { max }}=10.0 \mathrm{~N} / \mathrm{m}, k_{r \text { max }}=10.0 \mathrm{~N} \cdot \mathrm{m}$ と設定寸る. また, 同 時にフレーム要素とパネル要素も設計要素とし, 各設定 条件は 3.2 の場合と同一とした.

結果を表 1 及ひ図 10 に示寸. 表 1 において $\rho_{k}$ の值 は, 上から図 9 の $1 \sim 5$ に対応する. 最上部と最下部で $\rho_{k}$ の值が大きくなっており,この場合は上下端を溶接す るのが適切であるということを示している.この結果は 力学的にも合致したものである.

3. 5 T字型接合部の最適補強形状 続いて, パネル要素を用いて, 自動車ボデーのT字型接合部の最 適な補強形状を導出する.設計領域は図 1 1-(a)に示す. フレームと外部のパネルを非計要素とし,内部の補強 パネルを設計要素とする. 荷重条件は, 図 1 1-(b)の位 置にマルチローディングでねじり $1.0 \mathrm{~N} · \mathrm{~m}$ と垂直荷重 $10 \mathrm{~N}$ を加える.

結果を図 12 に示寸.図中(a) は通常パネルを用いた結 果で, 図中(b)はせん断パネルを用いた結果である. 両者 の形状に大きな相違が見られないのは,この問題はせん 断応力が支配的であるからであると考えられる.中央部

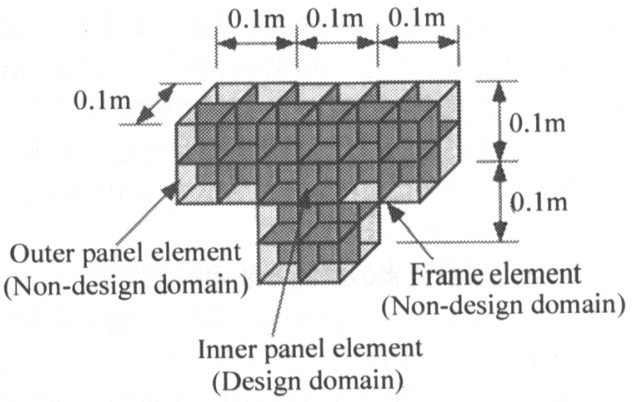

(a) Design and non-design domains
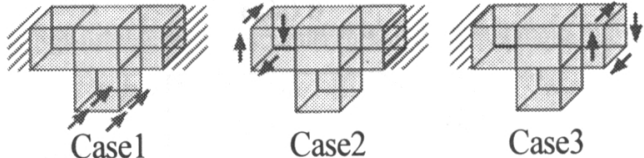

Case2

(b) Loading and boundary conditions Fig.11 Initial optimization settings for panel reinforcements in T-shaped body part

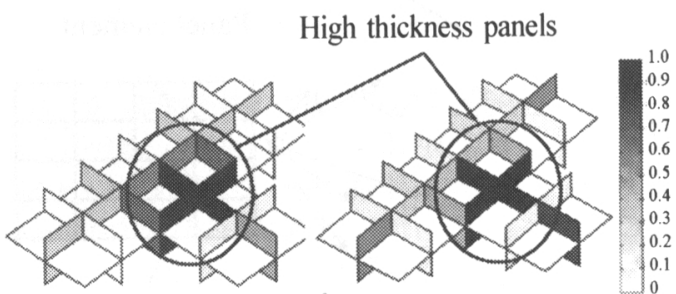

(a)Normal panel used '

(b) Shear panel used

Fig. 12 Optimal configurations of reinforcements in T-shaped body part 


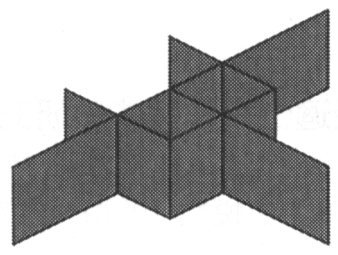

Fig. 13 Optimal normal panel reinforcements forTshaped body part

に厚いパネルが生じているのは, Caselの荷重及びCase2, Case3の稀じりを受けるためのものと考えられる.この検 討により考えられる理想的な補強形状を図 13 に示寸. このようにして,本手法により有効な補強力法が得られ ることがわかった.

\section{4. 結言}

本研究では,機械製品開発における構想設計段階での 設計支援を目的とした, フレーム要素, パネル要素, ば 衫要素を用いたトポロジ一最適化法を開発するとともに, 簡単な数值例により, 本研究で提案する方法の妥当性を 検証した. 結果を以下に示寸。

(1)構想設計段階で最も一般的な最適化問題である剛 性最大化問題について, 目標関数の定式化を行うととも に, フレーム要素, パネル要素, ば称要素の各離散化要 素における設計変数を設定し,その設定に基づき各要素 の定式化を行った.

(2)マルチローディングの考え方を基に, 最適化問題 を定式化し, 逐次凸関数近似法を用いたトポロジー最適 化アルゴリズムを構筑した.

（3）真応力とせん断応力を支持できる通常のパネル と,せん断応力のみを支持するせん断パネルから得られ る最適構造を比較することにより,構造の力学的メカ二 ズムを明確化できることを,簡単な数值例を用いて検証 した.

(4)フレーム要素とパネル要素を同時に設計要素とし て最適化することにより,体積制約の相違と最適解の関 係, 並びに設計要素の機能と最適解の関係を明確化した. さらに, ばね要素を設計要素に加えることで, 最適なば ね要素の配置と最適構造が同時に得られることがわかっ た.

(5) 自動車ボデーのT字型接合部を模した設計モデル により,最適な補強形状が得られることが確認できた.
Integration and Implementation of Computer Aided Engineering and Related Manufacturing Capabilities into Mechanical Product Development Process, (1980), Gi-Jahrestagung.

(2) Clausing, D. Quality Function Deployment, Cambridge: MIT Press, (1994).

(3) Nishigaki, H., Nishiwaki, S., Amago, T., and Kikuchi, N., First Order Analysis for Automotive Body Structure Design, ASME DETC 2000/DAC14533,(2000).

(4) Bendsøe, M. P. and Sigmund,O., Topology Optimization, (1994), 221-259, Springer.

(5) Kirsh, U., Optimal Topologies of Structures, Applied Mechanics Reviews, 42(1989), 223-238.

(6) 西脇眞二・西垣英一・鶴見康昭・小島芳生・菊 地昇，機論，65-662, C (2001), 3069-3077.

（7）藤井大地, パソコンで解く構造デザイン, (2002)，26-90，丸善.

(8) Suzuki, K. and Kikuchi, N., Comput. Methods Appl. Mech. Engrg., 93(1991), 291-318.

(9) Bendsøe, M. P. and Kikuchi, N., Comput. Methods Appl. Mech. Engrg., 71(1988), 197-224.

(10) Yang, R. J. and Chahande, A. I., Struct. Opt., 9 (1995), 245-249.

(11) 関口美奈子 - 㐘池昇, 日本計算工学会講演会 論文集，4(1999-5)，131-134.

(12) Fleury, C. and Braibant, V., Int. J. Num. Methods Engrg., 23 (1986),409-428.

\section{文献}

(1) Lemon, J. R., Tolani, S. K. and Klosterman, A. L., 